\title{
TINGKAT KEPUASAN PETANI TERHADAP PENGGUNAAN BENIH JAGUNG HIBRIDA DI DESA SINGKALAN KECAMATAN BALONGBENDO KABUPATEN SIDOARJO
}

\author{
LEVEL OF FARMER'S SATISFACTION WITH THE USE OF HYBRID CORN SEED \\ IN SINGKALAN VILLAGE, BALONGBENDO DISTRICT, SIDOARJO REGENCY
}

TRI WAHYU NURMAVINA*, TEGUH SOEDARTO, INDRA TJAHAJA AMIR

Fakultas Pertanian Program Studi Agribisnis

Universitas Pembangunan Nasional "Veteran" Jawa Timur, Surabaya

*E-mail : tnurmavina@gmail.com

\begin{abstract}
ABSTRAK
Kenaikan produksi jagung tidak lepas dari penggunaan benih jagung yang unggul, salah satu benih yang digunakan adalah benih jagung hibrida. Hal ini berdampak pada semakin luasnya pasar di Indonesia sehingga menyebabkan persaingan pasar yang semakin tinggi serta setiap produsen bersaing untuk mencari konsumennya. Salah satu cara untuk mendapatkan konsumen adalah dengan mengetahui tingkat kepuasan konsumen. Tingkat kepuasan konsumen terhadap suatu produk dipengaruhi oleh sekumpulan atribut yang dimiliki oleh produk tersebut. Desa Singkalan adalah salah satu desa yang memiliki luas lahan produksi jagung terbesar di kecamatan Balongbendo kabupaten Sidoarjo Jawa Timur. Dimana di desa tersebut sebagian besar petani menggunakan benih jagung hibrida Pertiwi 3 untuk menanam jagung. Tujuan dari penelitian ini yaitu (1) mengidentifikasi karakteristik pengguna benih jagung hibrida 3 di Desa Singkalan (2) menganalisis tingkat kepuasan petani terhadap penggunaan benih jagung hibrida Pertiwi 3 di Desa Singkalan. Metode analisis yang digunakan yaitu metode analisis deskriptif, Importance and Performance Analysis (IPA) dan Customer Satisfication Index (CSI). Hasil Analisis IPA menunjukkan bahwa terdapat empat atribut yang memiliki kinerja baik sehingga layak untuk dipertahankan salah satunya yaitu produktifitas. Sedangkan berdasarkan analisis CSI diperoleh tingkat kepuasan petani yaitu sebesar 69\% yang dapat diartikan bahwa petani puas terhadap penggunaan benih jagung hibrida Pertiwi 3.
\end{abstract}

Kata Kunci : Kepuasan Konsumen, IPA, CSI

\section{ABSTRACT}

The increase in corn production cannot be separated from the use of superior corn seeds, one of which is hybrid corn seeds. This has an impact on the wider market in Indonesia, causing higher market competition and each producer competing to find consumers. One way to get consumers is to know the level of customer satisfaction. The level of consumer satisfaction with a product is influenced by several attributes possessed by the product. Singkalan village is one of the villages that has the largest corn production area in Balongbendo sub-district, Sidoarjo district, East Java. Where in the village most of the farmers use Pertiwi 3 hybrid corn seeds to plant corn. The objectives of this study are (1) to identify the characteristics of the users of hybrid corn seeds in Singkalan Village (2) to analyze the level of farmer satisfaction with the use of Pertiwi 3 hybrid corn seeds in Singkalan Village. The analytical method used in this research is descriptive analysis method, Importance and Performance Analysis (IPA) and Customer Satisfication Index (CSI). The results of the IPA analysis show that there are four attributes that have good performance so that they are feasible to maintain, one of which is productivity. Meanwhile, based on the CSI analysis, the level of farmer satisfaction is 69\%, which means that farmers are satisfied with the use of Pertiwi 3 hybrid corn seeds.

Keywords : Cunsomer Satisfaction, IPA, CSI 


\section{PENDAHULUAN}

Jagung sekarang sudah menjadi barang komoditi bagi perusahaan benih untuk dapat mengambil pangsa pasar yang lagi berkembang di indonesia. Oleh karena itu jagung merupakan salah satu komoditi yang mampu mendongkrak pertumbuhan ekonomi masyarakat khususnya masyarakat petani dan pedagang (Hadus dkk., 2017). Jagung di Indonesia umumnya digunakan sebagai bahan pangan sebesar $50 \%$ dan lainnya dimanfaatkan sebagai pakan ternak. Berdasarkan data dari Badan Pusat Statistik tahun 2018 Luas panen jagung di Indonesia antara tahun 2017 sampai tahun 2018 mengalami peningkatan sebesar 3,64\% dan luas panen jagung terbesar yaitu provinsi jawa timur dengan luas panen lebih dari 1.200.000 Ha. Di Jawa Timur yang memiliki tingkat produksi jagung terendah yaitu Kabupaten Sidoarjo yang hanya menyumbang $0,12 \%$ produksi jagung di Jawa Timur. Di Sidoarjo yang memproduksi jagung terbesar salah satunya yaitu di desa Singkalan kecamatan Balongbendo dengan luas lahan produksi jagung sebesar $25 \mathrm{Ha}$.

Benih berdasarkan Br Kabeakan dan Manik (2020) merupakan salah satu sarana produksi yang penting dalam budidaya jagung. Salah satu upayanya yaitu menggunakan benih jagung hibriba pada saat penanaman. Satimela et al (2006) menyatakan bahwa varietas hibrida merupakan varietas unggul hasil pemuliaan tanaman yang terbukti mampu berproduksi $15 \%$ lebih baik dibandingkan varietas bersari bebas. Benih jagung hibrida merupakan hasil persilangan dua varietas sejenis yang berbeda dengan sifat induknya untuk mendapat sifat unggul dari masing-masing induknya. Benih jagung yang banyak digunakan di desa Singkalan adalah Benih Jagung Hibrida Pertiwi 3. Benih jagung pertiwi 3 memiliki keunggulan diantara benih yang lain diantaranya yaitu tahan terhadap penyakit bulai hawqar dan penyakit daun. Kemudian jagung yang dihasilkan memiliki tongkol yang besar dengan jumlah baris per tongkol 16 sampai 18 baris. Daun jagung akan tetap hijau walau tanaman sudah siap panen sehingga dapat dimanfaatkan sebagai pakan ternak. Benih jagung hibrida pertiwi 3 memiliki pesaing dari produsen benih jagung lainnya. Tantangan dan persaingan antar produsen benih semakin ketat dimana dibarengi dengan adanya kemajuan teknologi informasi yang menuntut produsen benih dalam merespon perubahan agar perusahaan tetap bertahan. Dengan adanya kemajuan teknologi konsumen akan lebih banyak menuntut, dan apabila tuntutan 
tersebut tidak terpenuhi maka konsumen akan mencari produk lain yang dapat memenuhi keinginanya sampi konsumen merasa puas. Penggunaan benih jagung hibrida tak terlepas dari karkateristik penggunanya.

Karakteristik konsumen dapat mempengaruhi pilihan konsumen terhadap produk maupun merk yang akan dibeli. Berdasarkan Sumarwan (2002), pengalaman dan pengetahuan konsumen, kepribadian konsumen dan karakteristik demografi merupakan karakteristik konsumen. Karakteristik demografi meliputi beberapa indikator seperti umur, tempat tinggal, jenis kelamin, pekerjaan, pendidikan dan lain-lain. Mengetahui karakteristik yang yang dimiliki oleh petani diyakini mamapu memberikan efek yang berbeda pada variabel yang lain seperti sikap yang mereka miliki (Soedarto dan Hendrarini, 2017)

Kepuasan pelanggan menurut Sadeli dkk. (2016) adalah faktor yang penting untuk keberhasilan dalam bisnis dimana pengukuran kepuasan pelanggan perlu dilakukan guna meningkatkan kinerja produk. Kepuasan adalah perasaan yang senang ataupun kecewa yang dirasakan seseorang setelah membeli atau menggunakan barang dan jasa (Gadung dkk., 2015). Konsumen yang puas terhadap barang dan jasa maka mereka akan merasakan senang dan memungkinkan konsumen tersebut untuk berlangganan. Namun jika konsumen tersebut merasa kecewa maka konsumen tersebut tergolong dalam tidak puas, sehingga akan berpengaruh buruk terhadap penjualan. Dengan demikian, berdasarkan (Irawan, 2007) kepuasan konsumen adalah kondisi dimana harapan konsumen mamapu dipenuhi oleh produk atau jasa dan sejauh mana manfaatnya dapat disarakan sesuai harapan konsumen. Wahyudi dkk. (2019) menyatakan bahwa terdapat 4 elemen kepuasan, yaitu : 1) Harapan, yaitu keinginan yang telah terbentuk sebelum konsumen membeli suatu produk. 2) Prestasi, yaitu pengalaman yang didapatkan konsumen setelah menggunakan produk tersebut. 3) Perbandingan, yaitu membandingkan harapan yang diinginkan konsumen sebelum membeli produk dengan kinerja produk sesungguhnya. 4) Konfirmasi, yaitu pernyataan oleh konsumen bahwa produk tersebut sesuai dengan harapan, namun jika kinerja produk tidak sesuai dengan harapan maka maka akan menimbulkan diskonfirmasi. Kepuasan pelanggan dibangun dari perbedaan antara harapan atas pelayanan yang diinginkan dan pelayanan yang diterima (Lütkemeyer 
Filho dkk., 2015). Tujuan dari mengetahui kepuasn konsumen bagi perusahaan bukanlah mengkonfirmasi pelanggan sebagai konsumen jangka pendek, melainkan perwujudan pemeliharaan hubungan dengan konsumen yang berkelanjutan. Jika pelanggan dianggap hanya sebai subjek peningkatan laba perusahaan maka diakhirnya pelanggan tidak mengakui upaya perusahaan. Maka dari itu perusahaan yang memperhatikan kepuasan konsumen akan menyebabkan adanya loyalitas pelanggan (Tae Kim dkk. 2017).

Simamora (2008) menyatakan
bahwa indikator yang membentuk
kepuasan konsumen adalah atribut yang
dimiliki oleh produk. Atribut produk
adalah karakteristik yang membedakan
suatu produk dengan produk yang lainnya
serta menjadi faktor yang dipertimbangkan
konsumen dalam mengambil keputusan
tentang pembelian suatu produk.
Berdasarkan Irawati (2009), suatu produk yang berupa barang atau jasa pada dasarnya yaitu sekumpulan atribut yang dapat dibedakan atas ciri, fungsi dan manfaat. Ciri-ciri yang dimaksud dapat berupa ukuran karakteristik, komponen dan bagiannya, proses manufaktur, jasa, bahan dasar, penampilan, harga, susunan dan tanda merek. Manfaat bisa berupa kegunaan yang berhubungan dengan panca indra maupun kegunaan secara non material, seperti penghemat waktu, kesehatan dan lain-lain. Manfaat yaitu dapat berupa manfaat langsung atau manfaat tidak langsung. Atribut produk memiliki peranan penting terhadap pembentukan kepuasan konsumen. Konsumen melihat produk sebagai kumpulan atribut dengan kemampuan yang berbeda, dimana atribut ini dapat memberikan manfaat yang dicari dan dapat menimbulkan kepuasan. Maka dari itu perusahaan dituntut untuk menciptakn produk yang bias memenuhi keinginan dari konsumen (Arista dkk.,2021).

Pengukuran tingkat kepuasan suatu produk dapat dilakukan dengan metode, Importance and Performance Analysis (IPA) dan Customer Satisfaction Index (CSI). Menurut Mustikarini dkk. (2014) Metode IPA digunakan untuk mengetahui atribut yang perlu pertahankan atau disesuaikan antara tingkat kinerja dan kepentingan produk. Dan Metode CSI digunakan untuk mengetahui tingkat kepuasan secara keseluruhan melalui atribut produk. Penelitian terhadapan tingkat kepuasan konsumen pada bidang pertanian sudah pernah dilakukan pula oleh beberapa peneliti, objek yang diteliti diantaranya ada penggunaan pestisida, 
penggunaan benih, penelitian tersebut diantaranya dilakukan oleh Dian dan Anindita (2017) dan Prafithriasar dan Fathiyakan (2017)

Tujuan dari penelitian ini yaitu 1) mengidentifikasi karakteristik pengguna METODE PENELITIAN

Penelitian dilakukan di desa Singkalan Kecamatan Balongbendo Kabupaten Sidoarjo pemilihan lokasi dilakukan secara purposive atau sengaja dengan pertimbangan jika desa ini merupakan salah satu desa yang memiliki luas lahan panen jagung terbesar di kabupaten Sidoarjo. Penelitian ini dilakukan pada bulan Mei 2021. Metode pengambilan sampel menggunan sensus sampling yaitu sebanyak 38 petani yang menggunakan benih jagung hibrida pertiwi 3 di desa Singkalan Kecamatan Balongbendo kabupaen Sidoarjo (Sugiyono, 2003). Petani yang layak dijadikan sampel adalah petani yang telah menggunakan benih jagung hibrida tersebut lebih dari 2 kali.

Metode analisis dilakukan secara kualitatif dengan kuantitatif. Analisis kualitatif dilakuakn dengan metode deskriptif digunakan untuk mengetahui karakteristik petani yang menggunakan benih jagung hibrida pertiwi 3 . Berdasarkan Natawiria dan Riduwan benih jagung hibrida di Desa Singkalan (2) menganalisis tingkat kepuasan petani terhadap penggunaan benih jagung hibrida Pertiwi 3 di Desa Singkalan.

(2010), analisis diskritif adalah analisis yang menjelaskan tentang suatu data yang dibuat secara peorangan maupun berkelompok. Analisis kuantitaif dilakukan menggunakan dua metode yang pertama yaitu Importance Performance Analysis (IPA) digunakan untuk menilai kepentingan dan kinerja setiap atribut yang dimiliki benih jagung hibrida pertiwi 3 . Berdasarkan Sudiyarto dkk (2021), IPA adalah alat analisis untuk membandingkan tingkat kepentingan dengan tingkat kinerja. Berikut adalah atribut benih yang digunakan dalam penelitian ini yaitu 1) Produktivitas yaitu kemampuan untuk menghasilkan tanaman jagung yang dimiliki oleh benih jagung hibrida, 2) Ketahanan hama dan penyakit adalah kemampuan dari tanaman jagung untuk tetap tumbuh dan berproduksi meskipun diserang hama dan penyakit tanaman, 3) Daya tumbuh merupakan kisaran presentase tumbuh tanaman jagung yang tercantum pada kemasan dengan presentase keberhasilan tanaman jagung tumbuh disawah petani, 4) Warna biji 
merupakan warna kuning yang dihasilkan dari bulir daging buah jagung setelah kelobot terkelupas, 5) Umur panen adalah keterangan perkiraan umur tanaman dan umur panen pada kemasan dengan keseuaian panjang daur hidup tanaman jagung, 6) Tongkol adalah Kondisi tongkol jagung dimana bulir jagung mengisi penuh sampai ujung tongkol, 7) Harga benih yaitu nilai nominal uang yang dibayarkan konsumen untuk mendapat benih jagung hibrida di toko pertanian, 8) Benih bersertifikat yaitu sertifikasi terhadap benih yang meiliki kualitas yang baik, 9) Ketersediaan benih yaitu ada tidaknya benih jagung hibrida yang siap dijual saat petani hendak membeli, 10) Daya simpan, dan 11) Promosi yaitu berupa potongan harga atau menggunakan benih gratis sehingga petani tertarik untuk menggunakan (Kurniawati, 2014).

\section{Importance Performace Analysis} (IPA) menurut Handriati dkk. (2015) yaitu dilakukan dengan mengetahui tingkat kesesuaian antara tingkat kepentingan dan tingkat kinerja atribut yang akan diteliti yaitu dengan membandingkan skor kinerja dan skor kepentingan. Kemudian menghitung rata-rata nilai kepentingan $(\mathrm{Y})$ dan kinerja (X) untuk setiap atribut. Lalu membuat batas dalam diagram kartesius dengan menghitung rata-rata seluruh atribut tingkat kepentingan $(\mathrm{Y})$ dan kinerja (X). Kemudian masing-masing atribut diuraikan dalam diagram kartesius. Menurut Supranto (2006), posisi atribut pada sumbu $X$ yaitu menunjukan penilaian skor rata-rata untuk tingkat kinerja dan untuk posisi atribut pada sumbu Y menunjukkan penilaian skror rata-rata untuk tingkat kepentingan. Diagram kartesius di bawah ini merupakan tahapan terakhir dalam penjabaran atribut dapat dilihat pada gambar 1 sebagai berikut :

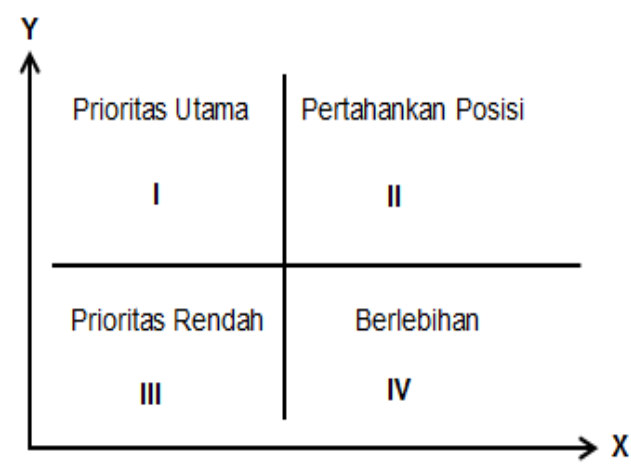

Gambar 1. Diagram Importance Perfomance Analysis (IPA), Hadrianti dkk. (2015)

Metode kedua yaitu Customers Satisfaction Index (CSI) digunakan untuk mengukur tingkat kepuasan petani secara menyeluruh terhadap penggunaan benih jagung hibrida pertiwi 3. Berdasarkan Patimah dkk. (2016) CSI yaitu metode yang digunakan untuk menentukan tingkat kepuasan konsumen secara menyeluruh dengan mempertimbangkan tingkat kepentingan dan kepuasan dari seluruh atribut yang telah diteliti. Menurut 
Stratford (2008), bahwa pengukuran indeks yaitu dengan empat tahapan. Pertama yaitu menentukan Means Importan Score (MIS) atau nilai rata-rata tingkat kepentingan dan Means Satisfaction Score (MSS) atau nilai ratarata kinerja tiap responden. Lalu menentukan Weight Factors (WF) yang merupakan nilai persentase dari MIS tiap atribut terhadap total MIS seluruh atribut yang diteliti. Selanjutnya menentukan Weight Score (WS) yang merupakan perkalian antara Means Satisfaction Score dengan Weight Factors. Kemudian dicari Customer Satisfaction Index (CSI) yang merupakan fungsi dari Weight Scor (WS) dibagi Highest Scale (HS). Tingkat kepuasan konsumen dapat diketahui dari kriteria indeks kepuasan konsumen. Simamora (2002) dalam Mustikarini (2014) mengatakan untuk membuat skala line arnumerik diawali dengan mencari rentang skala (RS)

Tabel 1. Kriteria Indeks Kepuasan Konsumen berdasarkan Startford (2008)

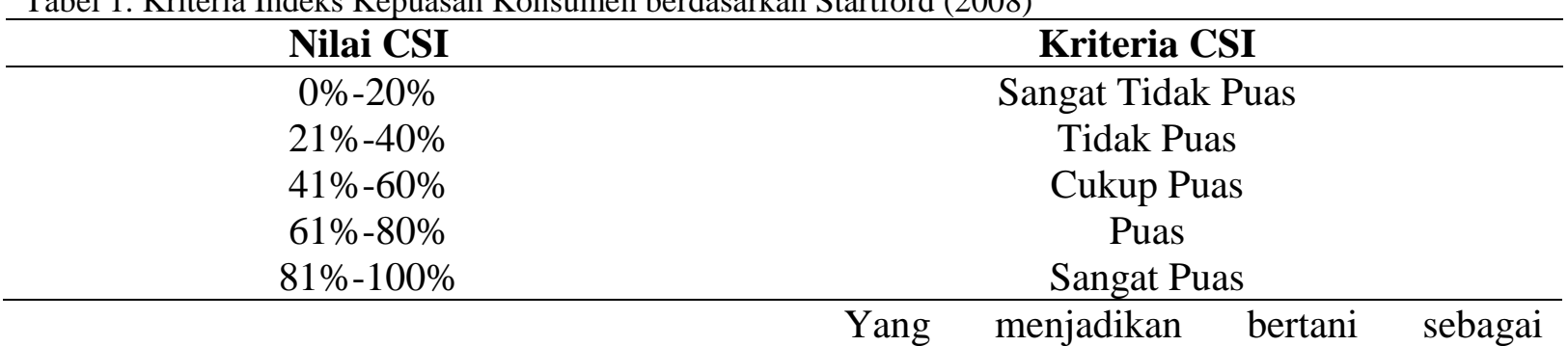

\section{HASIL DAN PEMBAHASAN}

\section{Karakteristik Petani}

Petani yang menjadi sampel sebanyak 38 petani yang terdiri dari $76 \%$ laki-laki dan $24 \%$ wanita dan memiliki usia lebih dari 50 tahun sebesar $76 \%$. Kemudian tingkat pendidikan petani yaitu sebesar $68 \%$ lulusan SD, $16 \%$ lulusan SMP dan SMA juga sebesar 16\%. Petani di desa Singkalan tidak ada yang menempuh pendidikan di Perguruan Tinggi. Selain sebagai petani, sebagian responden juga memiliki pekerjaan lain. Sehingga kegiatan bertani hanya dijadikan sampingan saja. pekerjaan utama sebesar $66 \%$ dan lainnya hanya menganggaap sebagai pekerjaan sampingan. Diperhatikan dari pengalaman bertani, sebanyak $58 \%$ petani yang telah melakukan budidaya jagung hibrida selama lebih dari 15 tahun dengan status kepemilikian lahan yaitu 37\% sewa, 50\% milik sendiri dan $13 \%$ dengan system bagi hasil. Yang dimaksud dengan bagi hasil adalah petani tersebut bergerak sebagai buruh di lahan untuk budidaya tersebut. Pengalaman menggunakan benih jagung hibrida pertiwi 3 dari petani sangat berpengaruh terhadap kepuasan petani. 
Dalam setahun petani biasanya menanam jagung sebanyak 2-3 kali. Karakteristik mempengaruhi petani dalam melakukan usahataninya. Sehingga dalam pemilihan benih yang merupakan sarana pendorong keberhasilan usahatani dipengaruhi pula oleh karakteristik. Berdasarkan penelitian yang dilakukan Prilierdi dkk.(2015), hubungan karakteristik petani yang meliputi umur, pendidikan dan pengalaman berusahatani memiliki hubungan yang positif terhadap usahatani semangka.

2. Peniliaian Tingkat Kinerja dan Tingkat Kepentingan Atribut Benih

\section{Jagung Hibrida dengan Metode}

\section{Importance Performance Analysis}

Metode Importance Performance Analysis digunkan untuk mengetahui mana saja atribut yang mempunyai tingkat kepentingan dan kinerja yang sesaui dengan harapan dari petani sebagi konsumen yang kemudian masing-masing atribut akan dijabarkan dalam diagram kartesius. Berdasarkan hasil dari metode IPA diketahui atribut dari benih jagung hibrida yang menunjukan tingkat kepentingan dan kinerja yang berbeda yang dikelompokkan dalam 4 kuadran yang terdapat di diagram kartesius yang dapat dilihat pada Gambar 1.

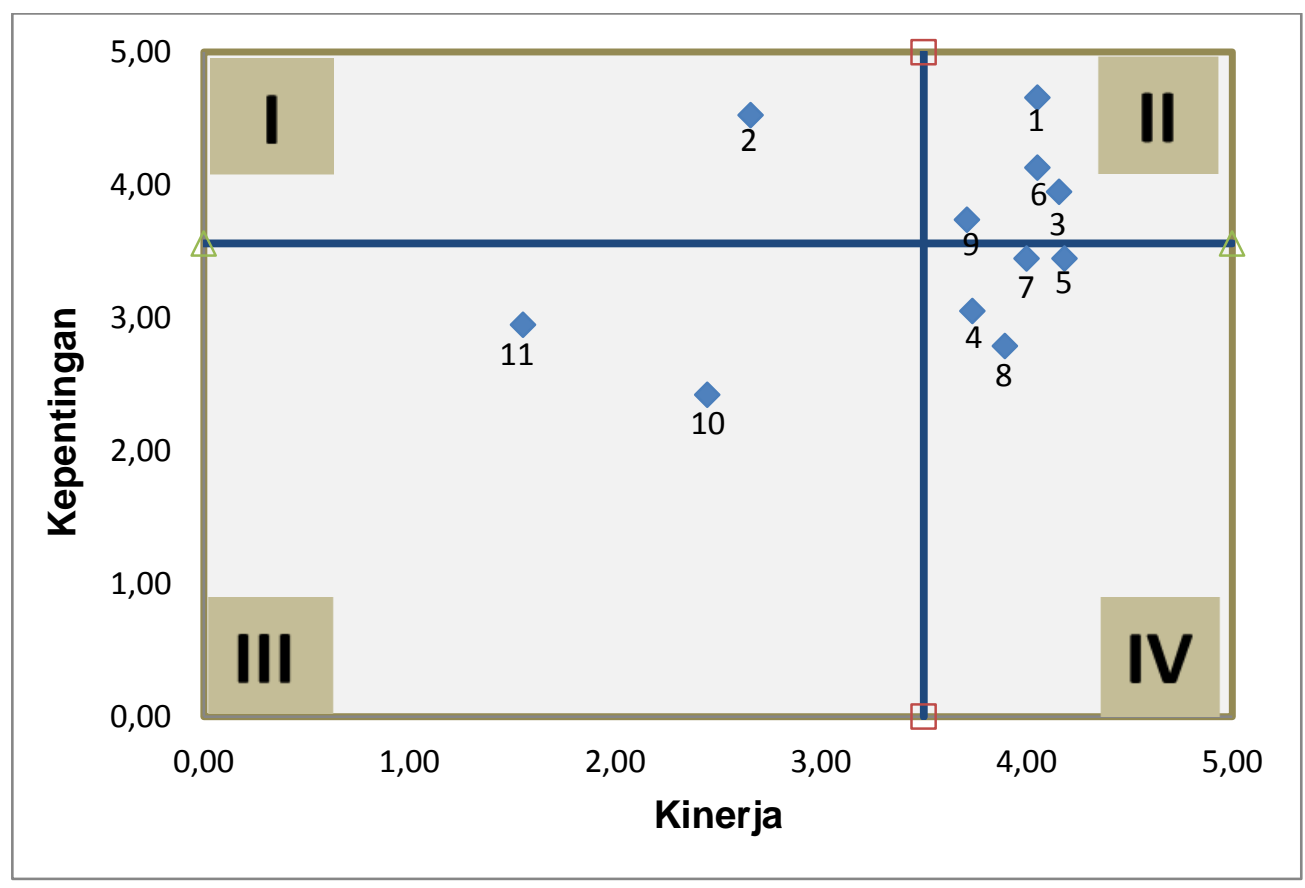

Gambar 2. Diagram IPA Atribut Benih Jagung Hibrida 


\section{Kuadran Pertama (Prioritas Utama)}

Kuadran pertama merupakan daerah yang menunjukkan ketidakpuasan konsumen terhadap atribut yang dimiliki benih jagung hibrida. Atribut yang ada dalam kuadran pertama dianggap memeiliki kepentingan yang tinggi menurut petani namun kinerja atribut tersebut masih kurang. Pada kaudran pertama terdapat atribut ketahanan hama dan penyakit. Ketahanan hama dan penyakit dianggap sangat penting oleh petani karena hal tersebut akan membantu petani dalam menghasilkan jagung yang berkualitas dan hasil yang memuaskan. Namun pada kenyataannya dalam menggunakan benih jagung hibrida Pertiwi 3 petani masing menggunakan obat-obatan untuk mengatasi hama dan penyakit yang menyerang tanaman jagung mereka.

\section{Kuadran Kedua (Pertahankan Posisi)}

Kuadran kedua merupakan daerah yang menunjukkan atribut yang perlu untuk dipertahankan kinerjanya. Pada kuadran ini tingkat kepentingan yang diharapkan petani dan tingkat kinerja yang diberikan oleh atribut tersebut sesuai atau memiliki tingkat yang sama tinggi, sehingga atribut tersebut dapat memberikan kepuasan kepada konsumen. di kuadran ini terdapat 4 atribut yaitu produktivitas, daya tumbuh, tongkol mepet atau penuh dan ketersediaan benih. Produktivitas benih ini mencapai 5 sampai 7 ton per hectare, angka tersebut telah sesuai dengan tingkat kepentingan yang diinginkan oleh petani. Daya tumbuh dari benih jagung hibrida pertiwi 3 cenderung memeiliki batang yang kekar dan berdaun lebat, hal tersebut dapat dimanfaatkan petani sebagai pakan ternak pula. Tongkol yang mepet atau penuh juga diinginkan oleh petani, dan hasil dari benih ini yaitu memeiliki tongkol yang mepet atau penuh. Dengan tongkol yang mepet sehingga dapat menarik pengepul untuk membeli jagung mereka. Kemudian ketersediaan benih juga tak kalah penting. Karene benih ini sangat mudah didapatkan di desa ini maka petani cenderung memilihi benih ini untuk dijadikan benih untuk budidaya jagungnya.

\section{Kuadran Ketiga (Prioritas Rendah)}

Kuadran ketiga merupakan daerah yang menunnjukan bahwa atribut yang dimiliki benih jagung hibrida Pertiwi 3 memiliki keinginan dan kenyataan yang sama-sama rendah, dimana atribut yang ada pada kuadran tersebut memiliki tingat kinerja dan tingkat keinginan yang sama rendahnya. Atribut tersebut adalah promosi dan daya simpan. Petani tidak terlalu memperhatikan daya simpan karena petani cenderung langsung menggunakan benih 
tersebut setelah membelinya tanpa harus menyimpanya terlalu lama benih tersebut.

\section{Kuadran Keempat (Berlebihan)}

Kuadran keempat merupakan daerah yang menunjukkan atribut yang memeiliki tingat kepentingan rendah namun memiliki kinerja yang tinggi. Pada kuadran ini terdapat atribut warna biji, umur panen, harga benih dan benih yang bersertifikat. Umur panen dianggap tidak terlalu penting karena hal tersebut sesuai dengan panen yang diinginkan petani dalam bentuk kering atau basah, jika dalam bentuk basah maka panen dapat dilakukan saat tanaman berumur kuramg lebih 2,5 bulan, jika panen kering sekitar 3 sampai 4 bulan setelah tanam. Kemudian benih jagung hibrida pertiwi 3 ini memiliki label sertifikasi berwarna biru yang tertera pada kemasannya, namun label tersebut dihiraukan oleh petani dan dianggap kurang penting.

\section{Kepuasan Petani terhadap Benih} Jagung Hibrida

Analisis kepuasan petani terhadap benih jagung hibrida varietas Pertiwi 3 dilakukan dengan metode Customer Satisfaction Index (CSI) yang menggunakan index untuk mengukur tingkat kepuasan petani yaitu pada tahap yang sangat tidak puas kemudian tidak puas, cukup puas, puas, dan yang terakhir sangat puas. Berdasarkan hasil perhitungan CSI diperoleh skor sebesar $71 \%$, dimana skor tersebut menunjukkan bahwa petani tergolong puas terhadap penggunaan benih jagung hibrida pertiwi 3. Yang termasuk dalam rentang puas yaitu $60 \%$ sampai 80\%. Hasil penelitian ini sejalan dengan penelitian Prafithriasari \& Fathiyakan (2017), bahwa nilai Customer Satisfaction Index (CSI) produk benih padi varietas lokal yang sebesar 94 persen yang berarti petani merasa sangat puas, persamaan yaitu petani sama-sama merasa puas PandanwangiBerikut adalah tabel hasil perhitungan menggunakan metode CSI 
Tabel 2. Hasil Perhitungan Menggunakan Metode Customer Satisfaction Index (CSI) produk Benih Jagung Hibrida Pertiwi 3

\begin{tabular}{|c|c|c|c|c|c|}
\hline & Atribut & MIS & MSS & WF & WS \\
\hline 1 & Produktivitas & 4.66 & 4.05 & 0.119 & 0.483 \\
\hline 2 & Ketahanan hama dan penyakit & 4.53 & 2.66 & 0.116 & 0.308 \\
\hline 3 & Daya Tumbuh & 3.95 & 4.16 & 0.101 & 0.420 \\
\hline 4 & Warna Biji & 3.05 & 3.74 & 0.078 & 0.292 \\
\hline 5 & Umur Panen & 3.45 & 4.18 & 0.088 & 0.369 \\
\hline 6 & Tongkol Penuh & 4.13 & 4.05 & 0.106 & 0.428 \\
\hline 7 & Harga Benih & 3.45 & 4.00 & 0.088 & 0.353 \\
\hline 8 & Benih Bersertifikat & 2.79 & 3.89 & 0.071 & 0.278 \\
\hline 9 & Ketersediaan Benih & 3.74 & 3.71 & 0.096 & 0.355 \\
\hline 10 & Daya Simpan & 2.42 & 2.45 & 0.062 & 0.152 \\
\hline 11 & Promosi & 2.95 & 1.55 & 0.075 & 0.117 \\
\hline & Total & 39.11 & 38.45 & 1.00 & 3.55 \\
\hline & CSI & \multicolumn{4}{|c|}{$71 \%$} \\
\hline
\end{tabular}

\section{KESIMPULAN DAN SARAN}

Berdasarkan hasil dan pembahasan diatas, maka kesimpulan yang dapat diambil yaitu Petani responden yang ada di desa Singkalan kecamatan Balongbendo yang menggunakan benih jagung hibrida pertiwi 3 sebaanyak 38 orang. Sebagian besar petani berjenis kelamin laki-laki dan berusia 50 tahun keatas. Kemudian pendidikan yang ditempuh responden sebagian besar adalah Sekolah Dasar. Status kepemilikan lahan untuk budidaya jagung 50\% milik sendiri. Berdasarkan perhitungan menggunakan metode IPA, atribut yang harus dipertahankan kinerjanya oleh perusahaan yaitu atribut produktifitas, daya tumbuh, tongkol yang penuh, dan ketersediaan benih, dimana atribut tersebut berada pada kuadran kedua. Kemudian berdasarkan perhitungan dengan menggunakan metode CSI diketahui bahwa dari seluruh atribut tersebut memiliki skor $71 \%$ yang menunjukkan petani merasa puas terhadap penggunaan benih jagung hibrida. Untuk meningkatkan kepuasan petani sebaiknya atributk ketahanan hama dan penyakit kinerjanya lebih ditingkatkan karena hal tersebut menurut petani memiliki tingak kepentingan yang tinggi. Kemudian atribut warna biji, umur panen, harga benih dan benih yang berlabel tidak perlu terlalu ditonjolkan kinerjanya, karena petani responden cenderong tidak memperhatikan itu dalam membeli benih.

\section{DAFTAR PUSTAKA}

Arista, Dita, Eva Dolorosa, dan Anita Suharyani. 2021. "Pengaruh Atribut Produk Kopi Bubuk Instan Indocafe terhadap Kepuasan dan Loyalitas Konsumen di Kota Pontianak." SEPA: Jurnal Sosial 
Ekonomi Pertanian dan Agribisnis 17

(2):

83.

https://doi.org/10.20961/sepa.v17i2 .38604 .

Br Kabeakan, Nana Trisna Mei, dan Juita Rahmadani Manik. 2020. "Kepuasan Dan Loyalitas Petani Jagung Menggunakan Benih Bersubsidi Di Desa Laubaleng Kecamatan Laubaleng Kabupaten Karo.” Jurnal Agrica 13 (2): 12435.

https://doi.org/10.31289/agrica.v13 i2.4093.

Dian, Febriana, dan Ratya Anindita. 2017. "Analisis Kepuasan Petani Bunga Krisan Potong terhadap Insektisida $\mathrm{X}$ di Desa Sidomulyo , Kecamatan Batu , Kota Batu." Jurnal HABITAT 28 (1): 28-36. https://doi.org/10.21776/ub.habitat. 2017.028.1.5.

Gadung, Adiguna, W Abbas Zakaria, dan Ktut Murniati. 2015. "Analisis Kepuasan dan Loyalitas Konsumen Kopi Bubuk Sinar Baru Cap Bola Dunia (SB-CBD) di Kota Bandar Lampung." JIIA 3 (4): 370-76.

Hadus, Eduardus, I Ketut Arnawa, dan I Made Tamba. 2017. "Analisis kepuasan petani terhadap biji hibrida benih hibrida f1 (Zea Mays Var Saccharata Sturt)." Jurnal Agrimeta 7 (14): 8-14.

Handriati, A. A., Sunaryo, dan V. N. Helia. 2015. "Analisis Kualitas Pelayanan Publik terhadap Kepuasan Konsumen dengan Menggunakan Metode Servperf-IPA-CSI." Journal UII 21 (4).

Irawan, Handi. 2007. 10 Prinsip Kepuasan Pelanggan. Jakarta: PT. Elex Media Komputindo.
Kurniawati, Febby. 2014. Analisis sikap, kepuasan, dan loyalitas petani terhadap benih jagung hibrida bisi2 di desa gadu barat, kecamatan ganding, kabupaten sumenep. Bogor: Institut Pertanian Bogor.

Lütkemeyer Filho, Mario Gilberto, Guilherme Luís RoeheVaccaro, dan Ernani Cesar de Freitas. 2015. "Identificação dos fatores de satisfação de clientes em serviços: Um estudo em concessionárias do agronegócio." Revista Brasileira de Gestao de Negocios 17 (58): 140825.

https://doi.org/10.7819/rbgn.v17i58 .1946.

Mustikarini, Fibria, Retnangsing, dan Megawati Simanjuntak. 2014. "Satisfaction and Loyalty to Pesticides among Paddy Farmers Abstract." ISSN : 1907-6037 7 (2): 93-102.

Natawiria, Asep Suryana, dan Riduwan. 2010. Statistika Bisnis. Bandung: Alfabeta.

Patimah, Siti, Basuki Sigit Priyono, dan Witman Rasyid. 2016. "Analisis Tingkat Kepuasan Konsumen Terhadap Pelayanan Usaha Benih Padi Cigeulis di Balai Induk Padi dan Palawida di Kabupaten Kepahiang Provinsi Bengkulu." Agrisep 15 (2): 203-12.

Prafithriasari, Merry, dan Gina Fathiyakan. 2017. "Analisis Sikap dan Kepuasan Petani dalam Menggunakan Benih Padi Varietas Lokal Pandanwangi ( Studi Kasus di Desa Bunikasih dan Desa Tegallega Kecamatan Warungkondang ).” Jurnal Agroscience 7 (2): 290-99.

Prilierdi, Ayogi, Rafeah Abubakar, dan 
Sutarmo Iskandar. 2015. "Hubungan Karakteristik Petani Terhadap Pendapatan Usahatani Semangka (Citrullus vulgaris) di Desa Sugih Waras Kecamatan Muara Sugihan Kabupaten Banyuasin." Societa 4 (1): 27-32. https://doi.org/ISSN 2301- 4180.

Sadeli, Agriani H., Hesty N. Utami, dan Rayi Rahmanissa. 2016. "Does customer satisfaction on product quality illustrates loyalty of agricultural product?" International Journal of Applied Business and Economic Research 14 (1): 22332.

Simamora, Bilson. 2008. Panduan Riset Perilaku Konsumen. Cetakan Ke. Jakarta: PT. Gramedia Pustaka Utama.

Soedarto, Teguh, dan Hamidah Hendrarini. 2017. "Farmers Characteristics, Ihsan Attitude , Economic Conditions and Socio-Cultural Environment Support as Activator of Farmer' $s$ Behavior to Meet Food Needs." International Journal of Social Relevance and Concern 5 (8): 77-92.

Sudiyarto, Indra Tjahaja Amir, dan Sri Widiyanti. 2021. "Analysis of Customer Satisfaction in
Purchasing Online Vegetable Products in Surabaya." Asian Journal of Management Science and Education 10 (1): 10-19.

Sugiyono. 2003. Metode Penelitian. Bandung: Alfabeta.

Sumarwan, Ujang. 2002. Perilaku Konsusmen. Bogor: Ghalia Indonesia.

Supranto. 2006. Mengukur Tingkat Kepuasan Pelanggan atau Konsumen. Jakarta: Rineka Cipta.

Tae Kim, Jung, Hyuk-Rae Jang, Sung Ho Cho, dan Yeong Hwang. 2017. "A Study on the Influence of Ecofriendly Agricultural Products on Customer Satisfaction and Behavior Intention in Hotel Chinese Restaurants." The International Journal of Advanced Culture Technology 5 (4): 63-70. https://doi.org/10.17703/IJACT.20 17.5.4.63.

Wahyudi, Daniel, Eka Sulistiani, dan Muhammad Haris Muhajat. 2019. "The impact of farmer's attitude and perceived quality to farmer's satisfaction and its effect on brand loyalty ." Journal Research in Business, Economics, and Education 1 (1): 45-57. http://ejournal.stie-kusumanegara.ac.id. 